\title{
光電比色分析法によるフェロアロイ中のニッケルの定量方法
}

\author{
（昭 和 31 年 11 月 13 日 受 理)
}

今井㻟也 ・南雲 信 光*

\section{[I ] 緒言}

さきに，われわれは，フェロアロイ中の銅の定量法について報 告した1)が，本報に拈いてはフェロマンガン・フェロシリコン， シリコマンガンおよびフェロモリブデン中のニッケルを光電比色 法により定量しょうと試みた結果を述べる。フェロアロイは鉄以 外の主成分を相当量含有 ( ${ }^{2)}$ ，鉄鋼分析方法をそのまま応用でき ないことが多いが，鉄鋼中のニッケルの比色定量法についてはす でに多くの研究があり ${ }^{3)}$, 広く実用化されている ${ }^{4,5,6,7)}$ ので, こ れらの方法に準じて実験を行い, 試料の分解, ニッケルの酸化, 妨害元素の除去等の実験条件を定め, フェロアロイに適当な定量 方法をえた。

\section{[II ] 実 験}

\section{1. 装固および試薬}

装置 : 吸光度の测定には平間式光電比色計 II 型, 日立分光光電 光度計 $\mathrm{EPU}-2$ 型を, $\mathrm{pH}$ の測定には東亜電波工業製 (HM 3) ガ

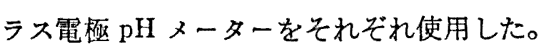

試薬：ニッケル標準溶液 $(46.6 \gamma \mathrm{Ni} / \mathrm{cc})$ : 結晶硫酸ニッケル （特級品） $2.3 \mathrm{~g}$ を水に溶解し, 正しく $500 \mathrm{cc}$ とする。この溶液 $50 \mathrm{cc}$ をさらに正しく 1 として保存する。濃度はジメチルグリ オキシム重量法により決定した。

クエン酸溶液 $(50 \%)$ ，ブロム水（飽和溶液）

ジメチルグリオキシム溶液 $(1 \%)^{8)}$ ：水酸化ナトリウム溶液 (1\%) $100 \mathrm{cc}$ 中にジメチルグリオキシム $1 \mathrm{~g}$ を溶解する。

ジチルグリオキシムアルコール溶液 $(1 \%)$, 塩酸ヒドロキシ ルアミン溶液 $(5 \%)$

\section{2. 予借操作}

ニッケル標準溶液一定量をとり，クエン酸, ブロム水を加えた 後アンモニア水で $\mathrm{pH}$ を調節し, ジメチルグリオキシムで発色さ せ全容を正しく $100 \mathrm{cc}$ としその一部を吸収セルにとり，540 $\mathrm{m} \mu$ の吸光度を測定する。ニッケルの酸化㓮としては種々の研究 が発表されている9 15)が，よく用いられているブロム4,7,10,16〜18)

†本報を「光電比色分析法によるフェロアロイ分析方法の研 究 (その 2)」とする.

* 日本電興株式会社研究課：東京都品川区.

1) 今井, 南雲, 工化 59, 886 (1956).

2) 日本工業規格, JIS G 2301 2316 (1953).

3) 単行本として E.B. Sandell, “Colorimetric Determination of Traces of Metals" (1953); F. D. Snell, C. T. Snell, "Colorimetric Methods of Analysis" (1954) 等がある。

4) 日本工業規格, JIS G 1216 (1953).

5) 池上, 神森, 分析化学 1, 73 (1952).

6）俵“鉄銅化学分析全書”下巻 p. 207 (1952).

7）日本学術振與会編，“鉄鋼迅速分析法” p. 145 (1956).

8）後藤，大高，日金属訫 14, 61 (1950).

9) 池田, 日化 $72,23,549$ (1951).
およびヨウ素5,19) の酸化作用について二, 三の検討の結果, 取报 いの便利なブロム水を使用することとした。

\section{3. 発色速度と呈色安定度}

ニッケルの発色は試薬添加後ただちに最大となり，長時間安定 であるが，鉄が共存する場合はクエン酸およびアンモニア水の添 加量が少ないと，時間ととすに吸光度をます。これを第 1 表に示す。

第 1 表 クエン酸, アンモニア水の添加量と吸光度

\begin{tabular}{|c|c|c|c|c|c|c|c|c|c|}
\hline \multirow{2}{*}{ 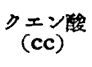 } & \multirow{2}{*}{$\underset{(\mathbf{c c})}{\mathrm{NH}_{4} \mathrm{OH}}$} & \multirow{2}{*}{$\mathrm{pH}$} & \multirow{2}{*}{ 成 分 } & \multicolumn{6}{|c|}{ 吸光度 $($ 発色後 $(\min ))$} \\
\hline & & & & 3 & 5 & 10 & 20 & 30 & $\overline{60}$ \\
\hline 4 & 10 & - & $\mathrm{Ni}$ & 0.108 & 0.108 & 0.108 & 0.108 & 0.108 & 0.108 \\
\hline " & " & - & $\mathrm{Fe}^{*}$ & 0.034 & 0.039 & 0.059 & - & - & - \\
\hline$"$ & $"$ & - & $\mathrm{Ni}+\mathrm{Fe}$ & 0.141 & 0.146 & 0.159 & - & - & - \\
\hline 10 & $"$ & - & $\mathrm{Fe}$ & 0.013 & 0.013 & 0.013 & 0.013 & 0.013 & 0.013 \\
\hline " & " & - & $\mathrm{Ni}+\mathrm{Fe}$ & 0.106 & 0.106 & 0.112 & 0.114 & 0.114 & 0.114 \\
\hline$"$ & 15 & - & " & 0.109 & 0.112 & 0.114 & 0.120 & 0.120 & 0.121 \\
\hline 15 & 8 & 9.0 & $"$ & 0.112 & 0.113 & 0.117 & - & - & - \\
\hline " & 10 & 9.3 & " & 0.106 & 0.106 & 0.106 & 0.107 & 0.107 & 0.107 \\
\hline$"$ & 15 & 9.9 & $"$ & 0.108 & 0.107 & 0.107 & 0.107 & 0.107 & 0.107 \\
\hline
\end{tabular}

第1図 ジメチルグリオキシムによる吸収曲線

\begin{tabular}{ccl} 
金属イオン & 添加䣵 $(\mathrm{mg})$ & 添 \\
\hline $\mathrm{Ni}$ & 0.047 & $\mathrm{NiSO}_{4}$ \\
$\mathrm{Fe}$ & 50 & $\mathrm{Fe}_{4}\left(\mathrm{SO}_{4}\right)_{8}$ \\
$\mathrm{Mo}$ & 50 & $\left(\mathrm{NH}_{4}\right)_{6} \mathrm{Mo}_{7} \mathrm{O}_{2}$ \\
$\mathrm{Mn}$ & 3 & $\mathrm{MnSO}_{4}$ \\
$\mathrm{Cu}$ & 1 & $\mathrm{CuSO}_{4}$ \\
$\mathrm{Cr}$ & 10 & $\mathrm{Cr}\left(\mathrm{SO}_{4}\right)_{8}$ \\
$\mathrm{Co}$ & 0.1 & $\mathrm{Co}\left(\mathrm{NO}_{3}\right)_{2}$
\end{tabular}

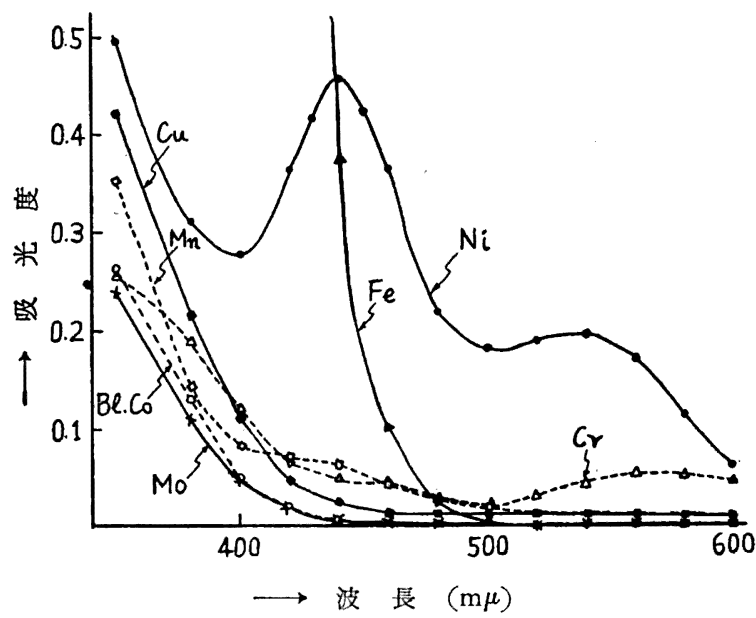

10) F. Feigl, J. Am. Chem. Soc. 57 B, 758 (1924).

11) B. Jones, Analyst 54, 582 (1929).

12) P. Wulf, A. Lundberg, Z, Ver. deut. Chem. 67, 71 (1948).

13) W. Oelschläger, Z. anal. Chem. 146, 339 (1955).

14) C. G. Hummon, Steel 114, 97 (1944).

15) O. R. Alexander, E. M. Godar, N. J. Linde. Ind. Eng. Chem. Anal. Ed. 18, 206 (1946).

16) A. M. Mitchell, M. G. Mellon, ibid. 17, 380 (1945).

17) W. M. Murry, Jr., S. E. Q. Ashley, ibid. 10, 1 (1938).

18) G. R. Makepeace, C. H. Craft, ibid. 16, 375 (1944).

19) IE. C. Pigott, "Ferrous Analysis" p. 306 (1953). 


\section{4. 吸収曲 線17)}

ジメチルグリオキシムによるニッケルの $350 \mathrm{~m} \mu$ から $600 \mathrm{~m} \mu$ までの吸光度を测定して第 1 因 $(\mathrm{Ni})$ の結果をえた。これより鉄 の影響を考虑して $540 \mathrm{~m} \mu$ の波長または主波長 $532 \mathrm{~m} \mu$ のフィ ルターを使用する。

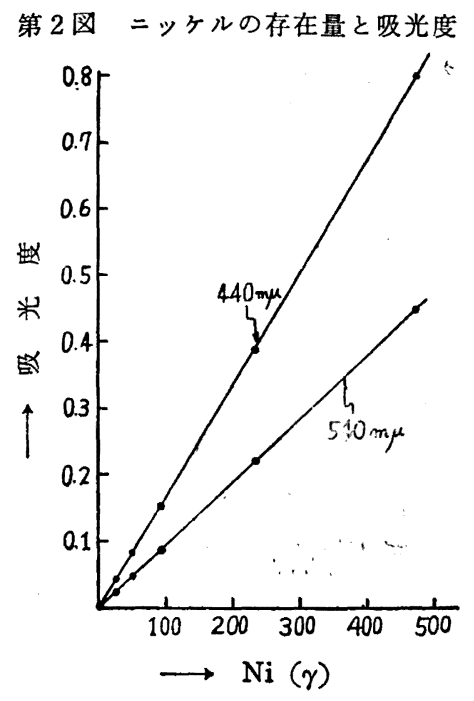

5. Beer の法則への 適合性

第 2 図のよ 5 に測定全 領域にわたり ニッケル 量と吸光度は直線性を示 す。

\section{6. 共存成分の影䛚}

ニッケル $46.6 \gamma$ に種 々の成分を共存させ，そ の検討結果を第 2 表に示 す。またこれらの成分が ジメチルグリオキシムに より示す吸收曲線の一例 を第 1 図に示す。本表か ら知られるように鉄が妨 害とならぬ使用波長を選 定すれば, マンガンのみがフェロアロイ中に抋いてはおるな検討 対象と限定される。なお試料の分解等に使用される硫酸, 硝酸, 塩酸はいずれる大なる妨害を与えなかった。

第 2 表 共存成分の影䈏

\begin{tabular}{|c|c|c|c|c|c|}
\hline \multicolumn{2}{|c|}{ 共存成分 (mg) } & \multirow{2}{*}{$\frac{\text { 吸光度 }}{0.109}$} & \multicolumn{2}{|c|}{ 共存成分 $(\mathrm{mg})$} & \multirow{2}{*}{$\frac{\text { 吸光度 }}{0.109}$} \\
\hline non & - & & \multirow[t]{2}{*}{$\mathrm{Mo}^{\mathrm{\theta}+}$} & 50 & \\
\hline $\mathrm{Mn}^{2+}$ & 0.15 & 0.108 & & 80 & 0.108 \\
\hline & 0.3 & 0.108 & \multirow[t]{3}{*}{$\mathrm{Cr}^{3+}$} & 0.05 & 0.108 \\
\hline & 0.6 & 0.116 & & 0.1 & 0.107 \\
\hline & 1.0 & 0.123 & & 1.0 & 0.106 \\
\hline \multirow[t]{3}{*}{$\mathrm{Cu}^{2+}$} & 0.05 & 0.109 & \multirow{3}{*}{$\mathrm{Cr}^{\theta+}$} & 10 & 0.185 \\
\hline & 0.12 & 0.124 & & 1.0 & 0.110 \\
\hline & 1.0 & 0.152 & & 5.0 & 0.114 \\
\hline \multirow[t]{2}{*}{$\mathrm{Co}^{9+}$} & 0.05 & 0.110 & & 50 & 0.114 \\
\hline & 0.1 & 0.109 & & & \\
\hline
\end{tabular}

\section{7. ほ量マンガンの妨害除去}

微量マンガンは大きな妨害原因とならないが，フェロマンガ ン, シリュマンガンのように多量にマンガンを含む2) 試料は，あ らかじめマンガンを除去して怙く必要がある。マンガンの除去方 法として, 二酸化マンガンとして分離する方法 ${ }^{11,20)}$ と, ニッケル をクロロホルム21 23)，またはベンゼンで抽出する方法とについ て検討した。

（1）二酸化マンガンとして分離する方法 木村の方法24)を応 用し好結果がえられた。すなわち一定量のニッケルを含むフェロ マンガン合成溶液※に硝酸, 塩素酸カリウムの添加量および煮沸 時間等を変えて二酸化、ンガンを析出させ, ガラスロ過器で吸引 口過後のロ液について、ニッケルおよびマンガン量を定量したと ころ第 3 表に示すような結果をえた。

20）後藤, 渡辺, 日金属 16, 286 (1952).

21) A. J. Hall, R. S. Young, Analyst 71, 479 (1946).

22) R. M. Sherwood, F. W. Chapman, Jr., Anal. Chem. 27, 88 (1955).

23) W. Nielsch, Z. anal. Chem. 143, 272 (1954).

24）木村, “無機定量分析” p. 247 (1952).

※フェロマンガン $(\mathrm{Mn} 80 \%, \mathrm{Fe} \mathrm{20 \% )} 0.5 \mathrm{~g}$ 相当.

\begin{tabular}{|c|c|c|c|}
\hline \multirow{2}{*}{$\begin{array}{c}\text { 第 } 3 \text { 表 } \\
\mathrm{KClO}_{3} \\
(\mathrm{~g})\end{array}$} & \multicolumn{3}{|c|}{ 塩素酸カリウムによるマンガンの分離 } \\
\hline & $\begin{array}{c}\text { 煮沸時間 } \\
(\mathrm{min})\end{array}$ & $\begin{array}{c}\mathrm{Mn} \text { 残存量 } \\
(\mathrm{mg})\end{array}$ & $\stackrel{\mathrm{Ni}}{\text { (吸光度) }}$ \\
\hline 2 & 2 & 大 量 & - \\
\hline 4 & 1 & 0.08 & 0.099 \\
\hline 4 & 4 & 0.24 & 0.115 \\
\hline 4 & 10 & 0.08 & 0.113 \\
\hline - & - & - & $0.109 \%$ \\
\hline
\end{tabular}

二酸化マンガン析出時の煮沸時間を必要以上に長くすると分析 所要時間を增すばかりでなく、ニッケルの定量值を低くするおそ れがある。また硝酸の添加量は約 $50 \mathrm{cc}$ が適当であった。この方 法はフェロマンガンにはそのまま適用できるが，シリコマンガン の場合には硝酸とフッ化水素酸で分解後, 硫酸 $(1+1) 5 \mathrm{cc}$ を 加えて加熱し, 白煙を発生させてから上記の操作を行う。硫酸を 多く加えると，口液中に残るマンガンの量が多くなる。

（2）クロロホルム抽出により分離する方法クロロホルムに よるニッケルの抽出はSandell ${ }^{25)}$ らの方法を伈用し好結果がえら れた。すなわち分液漏斗に一定量の試液をとり，これにクェン 酸, 塩酸七ドロキシルアミンを加え, アンモニア水で $\mathrm{pH}$ を調節 し, ジメチルグリオキシムアルコール溶液 $3 \mathrm{cc}$ 扰よびク口ロホ ルム $10 \mathrm{cc}$ を加えて 1 分間ふりまぜる。2 圈に分離後クロロホル ム層をあらかじめ塩酸 $(0.5 \mathrm{~N}) 25 \mathrm{cc}$ を入れてある分液漏斗に 移し， 1 分間ふりまぜる。2 層に分離後塩酸層をとり出しアンモニ ア水で $\mathrm{pH}$ を調節後, 常法によりニッケルを発色させ吸光度を測 定する。試料の分解等に使用される酸根の影響はなく, ニッケル の抽出は 1 回でも 2 㬝の分離を完全に行えば十分と思われるが， 2 回行えば完全である。抽出時の溶液の $\mathrm{pH}^{26}$ ) は 8 11 の検討 範间内では完全であった。その結果を第 4 表に示す。

$$
\text { 第 } 4 \text { 表 クロロホルムによる抽出 }
$$

\begin{tabular}{|c|c|c|c|c|c|c|c|c|}
\hline \multirow{2}{*}{\multicolumn{2}{|c|}{ 試 波 }} & \multirow{2}{*}{ 酸 } & \multirow{2}{*}{ 根 } & \multirow{2}{*}{ クエン酸 } & \multirow{2}{*}{$\underset{\mathrm{HCl}}{\mathrm{NH}_{2} \mathrm{OH} \cdot}$} & \multirow{2}{*}{$\begin{array}{l}\eta \text { 吅杰 } \\
\text { 给抽出 } \\
\text { 回数 }\end{array}$} & \multicolumn{2}{|c|}{ 吸光溲 } \\
\hline & & & & & & & $540 \mathrm{~m} \mu$ & $440 \mathrm{~m} \mu$ \\
\hline & $\mathrm{Ni}$ & & & 添加する & 添加せず & 抽出せず & 0.114 & \\
\hline & $"$ & & & 添加せず & $"$ & $"$ & 0.114 & \\
\hline & $"$ & & & 添加する & 添加する & 2 回 & 0.115 & 0.222 \\
\hline $\mathrm{Ni}+$ & FMn & & & $"$ & $"$ & $" \prime$ & 0.116 & 0.228 \\
\hline & $"$ & & & $"$ & $"$ & 1 回 & 0.112 & \\
\hline & " & & & 添加せず & $"$ & 2 回 & 0.117 & 0.235 \\
\hline & $n$ & & & 添加する & 添加せず & $"$ & 0.098 & \\
\hline & " $\mathrm{H}$ & $\mathrm{H}_{2} \mathrm{SO}_{4}(1+1)$ & $2 \mathrm{cc}$ & $"$ & 添加する & $n$ & 0.115 & \\
\hline & $" \stackrel{H}{+}$ & $\begin{array}{l}\mathrm{H}_{2} \mathrm{SO}_{1}(1+1) \\
\mathrm{NHO}_{3} 3 \mathrm{cc}\end{array}$ & $c^{1 \mathrm{cc}}$ & $"$ & $"$ & $"$ & 0.118 & \\
\hline
\end{tabular}

本法によれば, 鉄もニッケルから分離されるので, 感度のよい $440 \mathrm{~m} \mu$ 付近の波長で測定できる。

（3）ベンゼン抽出により分離する方法 クロロホルムの代り にペンゼンを用いてクロロホルム抽出の場合と全く同梯に操作し て, 同様な結果をえた。ベンゼンはクロロホルムにくらべて安価 であるが，水よりも比重が小さいので取扱いの面に不便があるの で，それ以上の実験は行わなかった。

\section{8. 操 作}

フェロマンガン：(1) 試料 $0.5 \mathrm{~g}$ をビーカーに科取し, 硝 酸 $50 \mathrm{cc}$ を加えて加熱分解後, 塩素酸カリウム $4 \mathrm{~g}$ を加え尛沸 して緑色のガスの発生が止んでからさらに 1 分間煮沸する。冷水 中に冷却後, ガラス口過器を用いて吸引口過し, 冷水で洗浄す

25) E. B. Sandell, R. W. Perlich. Ind. Eng. Chem. Anal. Ed. 11, 309 (1939).

26) A. Classen, L. Bastings, Rec. trav. Chim. 73, 783 (1954); Chem. Abst. 49, $2248 \mathrm{~g}$ (1955). 
る。口洗液を水でうすめて正確に $250 \mathrm{cc}$ とし，その $50 \mathrm{cc}$ を正 確にビーカーに分取, クエン酸溶液 $15 \mathrm{cc}$, ブロム水 $5 \mathrm{cc}$ を加 えてかきまぜた後，アンモニア水䄪 $10 \mathrm{cc}$ を加える。冷後ジメチ ルグリオキシム溶液 $3 \mathrm{cc}$ を加え, 水でうすめて正確に $100 \mathrm{cc}$ と する。液の一部を吸収セルにとり, $540 \mathrm{~m} \mu$ 付近の 波長で吸光度 を測定し、ニッケル量を算出する。

（2）試料 $0.5 \mathrm{~g}$ をビーカーに秤取し, 硝酸 $15 \mathrm{cc}$, 硫酸 $(1+$ 1） $5 \mathrm{cc}$ を加えて加熱分解する。冷後水で5すめて正確に $250 \mathrm{cc}$ とし，その $50 \mathrm{cc}$ を正確に $125 \mathrm{cc}$ の分液漏斗に分取し，クェン 酸溶液 $10 \mathrm{cc}$, 塩酸ヒドロキシルアミン溶液 $2 \mathrm{cc}$, アンモニア水 約 $3 \mathrm{cc}$ を加える。冷後ジメチルグリオキシム・アルコール溶液 $3 \mathrm{cc}$, クロロホルム $10 \mathrm{cc}$ を加え, 約 1 分間ふりまぜて静置す る。クロロホルム曆はあらかじめ塩酸 $(0.5 \mathrm{~N}) 25 \mathrm{cc}$ の入った $125 \mathrm{cc}$ の分液漏斗洺し，䄪 1 分間ふりまぜ静置する。塩酸層を ビーカーにとり，ブロム水 $5 \mathrm{cc}$ を加え，以下フェロマンガン （1）に準じて操作しニッケルを定量する。

フェロシリコン：(1) 陚料 $0.5 \mathrm{~g}$ を白金皿に科取 し, 硝酸 $10 \mathrm{cc}$, フッ化水素酸 $10 \mathrm{cc}$, 硫酸 $(1+1) 10 \mathrm{cc}$ を加えて加熱分 解し, さらに硫酸白煙を発生するまで加熱をつづける。冷後水で うすめて正確に $250 \mathrm{cc}$ とし, 以下フェロマンガン（1）に準じ て操作しニッケルを定量する。

シリコマンガン：（1）試料 $0.5 \mathrm{~g}$ を白金血に饰取 し，硝酸 $10 \mathrm{cc}$, フッ化水素酸 $5 \mathrm{cc}$, 硫酸 $(1+1) 5 \mathrm{cc}$ を加えて加熱分解 し,さらに硫酸白壁を発生するまで加熱をつづける。冷後少量の 水でうすめ, 硝酸 $50 \mathrm{cc}$ を加え, 以下フェロマンガン (1) に準 じて操作しニッケルを定量する。

（2）試料 $0.5 \mathrm{~g}$ を白金血に科取し（1）に準じて操作して 試料を分解，硫酸白煙を発生させる。冷後水でうすめて正確に $250 \mathrm{cc}$ とし, 以下フェロマンガン（2）に準じて操作しニッケル を定量する。

フェロモリブデン：(1) 試料 $0.5 \mathrm{~g}$ をビーカーに科取し, 硝 酸 $10 \mathrm{cc}$, 塩酸 $10 \mathrm{cc}$, 硫酸 $(1+1) 10 \mathrm{cc}$ を加えて加熱分解す る。冷後水でうすめて正確に $250 \mathrm{cc}$ とし，以下フェロマンガン （1）に準じて操作しニッケルを定量する。

[注 1] ニッケル量の算出は, ニッケル量既知のフェロアロイ を標準試料として検量線を作成し，利用寸るのが便利で ある。

[注 2] フェロマンガン, シリコマンガン操作（2）に拈いて は $440 \mathrm{~m} \mu$ の波長を使用すれば感度よく定量できる。

\section{[III ] 実 験 結 果}

上述の方法でえたニッケルの定量結果をジメチルグリオキシム 重量法と比較し第 5 表に示す。本法は迅速性 (20 分前後) の点 から考えても，フェロアロイ中のニッケルの日常分析法として適 当と考学る。

\begin{tabular}{|c|c|c|c|c|c|c|}
\hline \multirow{3}{*}{ 程 号 } & \multirow{3}{*}{ 実劇番号 } & \multicolumn{5}{|c|}{ フェロアロイ中のニッケルの定量結果 } \\
\hline & & \multirow{2}{*}{$\begin{array}{c}\text { 重筬法 } \\
\text { Ni } \\
(\%)\end{array}$} & \multicolumn{2}{|c|}{ 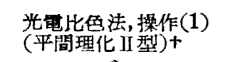 } & \multicolumn{2}{|c|}{ 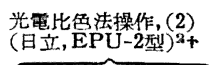 } \\
\hline & & & 昅光度 & $\mathrm{Ni}(\%)$ & 吸光度 & $\mathrm{Ni}(\%)$ \\
\hline \multirow{5}{*}{ FMn } & $1 *$ & 0.032 & 0.083 & 0.032 & 0.081 & 0.032 \\
\hline & 2 & 0.067 & 0.144 & 0.063 & 0.143 & 0.063 \\
\hline & 3 & 0.066 & 0.149 & 0.065 & 0.149 & 0.065 \\
\hline & 4 & 0.021 & 0.055 & 0.020 & 0.054 & 0.019 \\
\hline & $1 *$ & 0.030 & 0.055 & 0.030 & - & - \\
\hline \multirow{4}{*}{ FSi } & 2 & 0.024 & 0.051 & 0.023 & - & - \\
\hline & 3 & 0.034 & 0.053 & 0.029 & - & - \\
\hline & 4 & 0.029 & 0.052 & 0.029 & - & - \\
\hline & $1 *$ & 0.028 & 0.055 & 0.028 & 0.053 & 0.028 \\
\hline \multirow{5}{*}{ SiMn } & 2 & 0.046 & 0.085 & 0.043 & 0.093 & 0.046 \\
\hline & 3 & 0.033 & 0.067 & 0.034 & 0.067 & 0.033 \\
\hline & 4 & 0.041 & 0.072 & 0.037 & 0.073 & 0.038 \\
\hline & $1 *$ & 0.069 & 0.172 & 0.069 & - & - \\
\hline & 2 & 0.040 & 0.123 & 0.045 & - & - \\
\hline \multirow[t]{2}{*}{ FMo } & 3 & 0.042 & 0.100 & 0.040 & - & - \\
\hline & 4 & 0.048 & 0.125 & 0.051 & - & - \\
\hline
\end{tabular}

\section{[IV] 結論}

以上で光電比色法によるフェロアロイ中のニッケルの定量法に ついて報告した。すなわち

（1）比色に適するような，フェロアロイの種類に応じた分解 法を求める。

（2）主成分として大量にマンガンが存在するときは，次の操 作によりその妨害が除かれる。（i）塩素酸カリウムでマンガンを 酸化し，二酸化マンガンとして迅速に除去する方法。(ii) ク口ロ ホルムまたはベンゼンを用いてニッケルを抽出する方法。後者で は鉄もニッケルから分離されるので $440 \mathrm{~m} \mu$ の波長を用いて感度 よく定量できる。

（3）クロム，モリブデンは酸化して抢けば妨害とならない。

（4）本法は従来法（ジメチルグリオキシム重量法）にくらへ て日常分析法として便利であり，精度もよい。

(昭和 31 年 4 月, 日化第 9 年会で一部講演)

終りに本研究につき種々の御教示をいただた中央大学工学部 武藤義一氏に深く感謝する。 